\title{
Organic beef cattle production pattern at Shahjadpur upazilla of Sirajgonj district in Bangladesh
}

\author{
MD Hossain ${ }^{1}$, MM Hossain $^{1}$, MA Hashem ${ }^{1 *}, \mathrm{KJ} \mathrm{Bhuiyan}^{2}$ \\ ${ }^{1}$ Department of Animal Science, Bangladesh Agricultural University, Mymensingh 2202; ${ }^{2}$ Department of \\ Agricultural statistics, Bangladesh Agricultural University, Mymensingh 2202, Bangladesh
}

\begin{abstract}
The experiment was conducted to investigate the present status of organic beef cattle production at Shahjadpur upazilla of Sirajgonj district in Bangladesh through field survey. The data were collected based on a prescribed interview schedule from 30 respondents selected from 6 villages of Shahjadpur upazila who were involved in beef cattle production. Parameters studied were origin, feeds and fodder, breeding, health care, animal welfare and other factors related to organic beef cattle production. In this study, $12 \%$ cattle were indigenous and $88 \%$ crossbred in origin. $83 \%$ farmers used cultivated fodder and $17 \%$ used cultivated and roadside grass which was cultivated in their own land. However, $37 \%$ farmers used vitamin mineral supplementation. Among the farmers, $13 \%$ farmers used natural breeding, $73 \%$ farmers used A.I. and $14 \%$ both methods for livestock breeding. $87 \%, 80 \%$, and $83 \%$ farmers practiced vaccination, deworming and grooming, respectively while, $70 \%$ farmers used hormone, antibiotic and growth promoter for beef cattle production and only $33 \%$ farmers isolate sick or injured animal from healthy stock. 73\% farmers allowed access to outdoor and pasturing during winter season and only 3\% farmers kept their livestock record. 37\% farmers purchase cattle occasionally and $53 \%$ farmer's fattened cattle for 3 months and rest fattened for a prolonged period. In Bangladesh beef cattle are fatten in conventional method where different inorganic substances are used by the farmers. So there are great potentialities for organic beef cattle production in Bangladesh both for satisfying animal protein requirement and production of quality beef.
\end{abstract}

Key words: Bangladesh, Beef cattle, Organic production, Fattening

Bangladesh Animal Husbandry Association. All rights reserved.

Bang. J. Anim. Sci. 2016. 45 (1): 25-30

\section{Introduction}

Livestock is an integral component of agriculture and make multifaceted contributions to the growth and development in the agricultural sectors of Bangladesh. The livestock resources of Bangladesh are mainly based on cattle, goat, sheep, buffalo, and poultry. About 24.5 million cattle heads are distributed throughout the country which ranks $12^{\text {th }}$ in the world and $3^{\text {rd }}$ in Asian countries (FAO, 2010). Although the growth of livestock production is the second highest among all other sub-sector of agriculture in Bangladesh (BER, 2012), the production and consumption of livestock products is still much lower in consumption with other countries. According to the report, the requirement of meat per head per day is 120 $\mathrm{gm}$ whereas the availability is only $22 \mathrm{gm}$ (DLS, 2011) and the deficit of meat is more than $80 \%$ in 2010. To satisfy the animal protein requirement, beef fattening can play an important role.

Organic beef production is a means of food production with a large number of rules directed towards a high status of animal welfare, care for the environment, restricted use of medical drugs and the production of a healthy product without residues e.g. pesticides or medical drugs (Kijlstra and Eijck, 2006). But now a day inorganic fertilizer, pesticides, growth stimulating substances like hormones, steroids, feed additives etc. are using in Bangladesh for beef cattle production (Islam et al., 2012). Most of the beef cattle are fattened allegedly by unscrupulous cattle traders ignoring the scientific formula prescribed by Livestock Department. The information related to organic beef cattle production by the farmers in Bangladesh is very limited. No attention has been yet paid in respect of using growth

*Corresponding Author: hashem_mdabul@yahoo.com 
promoting steroids and feed additives in small scale cattle farming system. Detailed study is needed in different district of Bangladesh to know the present status and recommended organic beef cattle production program for the farmers as a value added income generating activities. For this, it is a prime importance to find out present status of organic beef cattle production in Bangladesh. Therefore, the present study was undertaken to know the present status of organic beef cattle production in Bangladesh.

\section{Materials and Methods}

The study was conducted in three unions namely: Rupbati, Potajia and Garadaha under Shahjadpur upazilla of Sirajgonj district in Bangladesh. The data was collected through interview schedule selecting 30 respondents involved in beef cattle production. Farmers were randomly chosen from each village. A structured interview schedule was carefully prepared and data were collected by one-to-one interview method from respondents. Along with their response practical observations were also applied for calibration of the results.

The interview schedule contained the following information; A) Check list of organic beef cattle production: origin of livestock, livestock feeds and fodders, livestock breeding, health care, animal welfare and record keeping of livestock (Chander et al., 2011). B) Others factors related to organic beef cattle production: education level, household size, occupation, land size of the farmers, training, source of capital, purchase time, duration of the program, problems in organic beef cattle production. At the end of data collection, the collected data were coded, compiled, tabulated and analyzed. The local units were converted into standard units.

The qualitative data were transferred into quantitative data by scoring technique. Data were carefully tabulated and analyzed with descriptive statistical method to fulfill the objectives of the study. Tabular technique was applied for the analysis of data using descriptive statistical tools like frequency, average and percentages through SPSS software.

\section{Results and Discussion}

\section{A) Check list of beef cattle production}

\section{Origin of beef cattle}

Table 1 shows the origin of beef cattle. In the study area about $12 \%$ cattle were indigenous and $88 \%$ crossbred in origin. Islam et al., (2012) working in three district where they showed that $43 \%$ indigenous and $57 \%$ crossbred cattle were used for beef cattle production. In organic beef cattle production cattle must be raised under continuous organic management from the last third of gestation (Chander et al., 2011). Indigenous breeds are adapted to local condition and resistance to disease but in the study area $88 \%$ use crossbred cattle for beef cattle production.

Table 1. Origin, source and breeding method of beef cattle

\begin{tabular}{lll}
\hline Parameters & Categories & $\begin{array}{c}\text { Respondents } \\
\text { (\%) }\end{array}$ \\
\hline Origin & Indigenous & $12(12)$ \\
& Crossbreed & $88(91)$ \\
Source & Own source & $63(19)$ \\
& Purchase & $37(11)$ \\
Breeding & Natural & $13(4)$ \\
method & A.I. & $73(22)$ \\
& Both & $14(4)$ \\
\hline
\end{tabular}

* The values within bracket indicate total number of respondents.

\section{Livestock breeding}

Breeding method of livestock shows in Table 1. In organic beef cattle production reproduction technique should be natural. Artificial insemination is allowed only upon veterinary necessity but in the study area $73 \%$ of farmers used artificial insemination technique and $14 \%$ of farmers used both natural and artificial insemination techniques.

\section{Livestock feeds and fodder}

Table 2 shows most of the farmers ( $83 \%$ ) used cultivated fodder and only $17 \%$ farmers used cultivated fodder and roadside grass during rainy season. About $37 \%$ farmers used commercial vitamin mineral supplement in feed for beef cattle production. In organic beef cattle production producers are required to feed 


\section{Beef cattle production in Bangladesh}

livestock agricultural feed products that are $100 \%$ organic and may also provide allowed vitamin and mineral supplements but in the study area most of the farmers used inorganic agricultural feed products and small number of farmers provide vitamin mineral supplement to cattle for beef cattle production.

Table 2. Sources of feeds and fodder for beef cattle

\begin{tabular}{lll}
\hline Parameters & Categories & $\begin{array}{c}\text { Respondents } \\
\text { (\%) }\end{array}$ \\
\hline Roughage & $\begin{array}{l}\text { Roadside } \\
\text { grass }\end{array}$ & $0(0)$ \\
& $\begin{array}{l}\text { Cultivated } \\
\text { fodder }\end{array}$ & $83(25)$ \\
& $\begin{array}{l}\text { Both } \\
\text { Compound }\end{array}$ & $17(5)$ \\
Concentrate & $\begin{array}{l}\text { feed/pellet } \\
\text { Mixed feed }\end{array}$ & $100(30)$ \\
Vitamin & Yes & $37(11)$ \\
mineral & No & $63(19)$ \\
supplement & Produce & $0(0)$ \\
concentrate & themselves & $100(30)$ \\
feed & Buy locally & $100(30)$ \\
Fertilizer use & Yes & $0(0)$ \\
\hline
\end{tabular}

"The values within bracket indicate total number of respondents.

\section{Livestock health care}

Livestock health care shows in Table 3. About $87 \%$ farmers vaccinate their beef cattle and $80 \%$ practiced deworming regularly. Most of the farmers $(70 \%)$ used hormones, antibiotic and growth promoter for higher meat production. About $67 \%$ farmers not isolated their sick animals from healthy stock. The results of this study are similar with Begum et al., (2007) where they reported that $83.3 \%$ farmers used vaccination, $80 \%$ farmers practiced deworming and $63.4 \%$ farmers grooming/bathing their cattle regularly. Organically raised animals may not be given hormones to promote growth or antibiotics for any reason. Preventive management practices, including the use of vaccines, will be used to keep animals healthy. Producers are prohibited from withholding treatment from a sick or injured animal; however, animals treated with a prohibited medication would be removed from organic operation (IFOAM, 2000). In the study area $87 \%$ farmers maintain vaccination schedule to keep animals healthy but majority of the farmers (70\%) used growth promoter and they did not practice isolation of sick animals from healthy animals.

Table 3. Livestock health care and condition $(n=30)$

\begin{tabular}{lc}
\hline Parameters & $\begin{array}{c}\text { Respondents } \\
(\mathbf{\%})\end{array}$ \\
\hline Vaccination & 87 \\
Hormone, antibiotic and & 70 \\
growth promoter & 33 \\
Removal of sick animals & 80 \\
Deworming & 83 \\
Grooming & 73 \\
Access to outdoor & 73 \\
Access to pasture & 27 \\
Separate male and female & \\
cattle & \\
\hline
\end{tabular}

Table 4: Status of organic and inorganic beef cattle production $(n=30)$

\begin{tabular}{|c|c|c|c|}
\hline $\begin{array}{c}\text { Check } \\
\text { list }\end{array}$ & Criteria & $\begin{array}{l}\text { Organic } \\
(\%)\end{array}$ & $\begin{array}{l}\text { Inorgan } \\
\text { ic }(\%)\end{array}$ \\
\hline \multirow[t]{2}{*}{ Breed } & $\begin{array}{l}\text { Indigenous/ } \\
\text { Crossbreed }\end{array}$ & 12 & 88 \\
\hline & Roughage & 0 & 100 \\
\hline \multirow{2}{*}{ Feed } & Concentrate & Unknown & Unknown \\
\hline & $\begin{array}{l}\text { Vitamin and } \\
\text { mineral }\end{array}$ & 37 & 63 \\
\hline \multirow[t]{2}{*}{ Breeding } & Natural/A.I. & 100 & 0 \\
\hline & Vaccination & 87 & 13 \\
\hline \multirow{3}{*}{$\begin{array}{l}\text { Health } \\
\text { care }\end{array}$} & $\begin{array}{l}\text { Growth } \\
\text { promoter }\end{array}$ & 30 & 70 \\
\hline & $\begin{array}{l}\text { Removal of } \\
\text { sick animal }\end{array}$ & 33 & 67 \\
\hline & $\begin{array}{l}\text { Access to } \\
\text { outdoor }\end{array}$ & 73 & 27 \\
\hline $\begin{array}{l}\text { Living } \\
\text { condition }\end{array}$ & $\begin{array}{l}\text { Access to } \\
\text { pasture }\end{array}$ & 73 & 27 \\
\hline $\begin{array}{l}\text { Record } \\
\text { keeping }\end{array}$ & $\begin{array}{l}\text { Kept/Not } \\
\text { kept }\end{array}$ & 3 & 97 \\
\hline
\end{tabular}

\section{Present status of organic beef cattle production}

In the parameter of breed $12 \%$ cattle are organic and $88 \%$ inorganic. In case of roughage $100 \%$ of the feeds are inorganic because most of the farmers use inorganic fertilizer and pesticides for fodder production. About 37\% cattle are organic and $63 \%$ cattle are inorganic in criteria of providing vitamin mineral supplement. In the parameter of livestock breeding about $100 \%$ cattle are organic. In organic beef cattle production hormone, 
Hossain et al. (2016) Bang. J. Anim. Sci. 45(1): 25-30

Table 5: Associated factors related to organic beef cattle production

\begin{tabular}{|c|c|c|c|}
\hline Parameter & Categories & $\begin{array}{l}\text { Number of } \\
\text { respondents }\end{array}$ & $\begin{array}{c}\text { Respondents } \\
(\%)\end{array}$ \\
\hline \multirow{3}{*}{ Age } & Young age (up to 35 years) & 6 & 20 \\
\hline & Middle age ( $36-50$ years) & 14 & 47 \\
\hline & Old age (above 50 years) & 10 & 33 \\
\hline \multirow{3}{*}{ Household size } & Small family (up to 5 members) & 13 & 43 \\
\hline & Medium family (6-8 members) & 11 & 37 \\
\hline & Large family (above 8 members) & 6 & 20 \\
\hline \multirow{3}{*}{ Land size } & Marginal (up to 1 acre) & 7 & 23 \\
\hline & Small (1-3 acre) & 12 & 40 \\
\hline & Medium (above 3-8 acre) & 9 & 30 \\
\hline \multirow{5}{*}{ Level of education } & Large (above 9 acre) & 2 & 7 \\
\hline & Primary & 14 & 47 \\
\hline & SSC & 10 & 33 \\
\hline & $\mathrm{HSC}$ & 6 & 20 \\
\hline & Agriculture & 21 & 70 \\
\hline \multirow[t]{2}{*}{ Occupation } & Business & 7 & 23 \\
\hline & Govt. job & 2 & 7 \\
\hline \multirow{3}{*}{ Source of capital } & Own capital & 23 & 76 \\
\hline & Bank loan & 5 & 17 \\
\hline & NGO loan & 2 & 7 \\
\hline \multirow{2}{*}{ Training } & Have & 2 & 7 \\
\hline & Have not & 28 & 93 \\
\hline \multirow{3}{*}{ Purchase time } & Around the year & 0 & 0.0 \\
\hline & Occasionally & 11 & 37 \\
\hline & Not purchase & 19 & 63 \\
\hline \multirow{3}{*}{ Duration of program } & 3 months & 16 & 53 \\
\hline & 6 months & 11 & 37 \\
\hline & More than 6 months & 3 & 10 \\
\hline
\end{tabular}

Table 6: Problems and suggestions to improve organic beef cattle production

\begin{tabular}{lcc}
\hline \multicolumn{1}{c}{ Problems/Suggestion } & $\begin{array}{c}\text { Number of } \\
\text { respondents }\end{array}$ & $\begin{array}{c}\text { Respondents } \\
\text { (\%) }\end{array}$ \\
\hline Anywhere and everywhere use of growth promoter & 19 & 63 \\
High cost of vitamin mineral supplementation & 17 & 57 \\
Unavailable organic fertilizer & 13 & 43 \\
Lack of indigenous breed & 7 & 23 \\
Lack of pasture land & 9 & 30 \\
Lack of technical knowledge & 5 & 17 \\
Lack of training facilities & 3 & 10 \\
Restricted use of growth promoter & 18 & 60 \\
Green manure should be available & 10 & 33 \\
Reduce supplementation cost & 17 & 57 \\
Pasture land should be available & 8 & 27 \\
Providing training facilities & 4 & 13 \\
Motivation of the farmers & 3 & 10 \\
\hline
\end{tabular}


antibiotic, and growth promoter is prohibited but $70 \%$ farmers use growth promoter. Consideration of living condition and record keeping, 73 and 3 per cent cattle respectively are to be organic (Table 4).

\section{Record keeping}

Table 4 shows most of the farmers not kept their livestock record with sufficient information and only a few kept birth record, breeding record, feed record, health record etc. for beef cattle production. Even though, farmers were completely unknown about the importance of keeping records in a livestock farm.

\section{B) Associated factors related to organic beef cattle production}

Table 5 shows the others factors related to organic beef cattle production. The results of this study were similar with Rahman et al., (2012) where they reported that $45.3 \%, 16 \%$ and $38.7 \%$ farmers were in middle, young and old aged category respectively. They also reported that $52 \%$ farmers had small sized, $31 \%$ medium and $17 \%$ farmers' large family. Almost similar findings were found by Begum et al., (2007), Ahamed et al., (2010). Among the total respondents $47 \%$ completed primary education while $33 \%$ had secondary and $20 \%$ had higher secondary level of education (Table $5)$. The results of this study were similar with Begum et al., (2007), where they found that $20 \%$ farmers illiterate, $40 \%, 30 \%$ and $10 \%$ farmers completed primary, secondary and above secondary level of education respectively in Panchagarh district. They also reported that $86.7 \%$ used own capital for beef cattle production. Out of 30 respondents, $70 \%$ were involved in agriculture, $23 \%$ in business and $7 \%$ in government job. The results of this study were similar with Ahamed et al., (2010) and reported that $70.2 \%$ farmers involved in

\section{References}

Ahamed T, Hashem MA, Khan M, Rahman MF and Hossain MM (2010). Factors related to small scale cattle fattening in rural areas of Bangladesh. Bangladesh Journal of Animal Science, 39 (1-2): 116-124.

Ali MA and Anwar ABMN (1987). Cattle problem confrontation in a union of Mymensingh. agriculture and $11.2 \%$ in business. Table 6 shows most of the farmers fattened cattle for 3 months and rest of them fattened a prolonged period. While working with the farmers in rural areas of Bangladesh, Hossain (1986) and Hossain et al., (1996a) reported cattle fattening periods of 4 to 5 months and 5 to 7 months, respectively.

\section{Problems faced by the farmers and their suggestions}

Problems faced by the farmers and their suggestions to improve organic beef cattle production shows in Table 6. Like our findings, Ali and Anwar (1987) and Hossain et al., (1996b) found that high feed cost and shortage of animal feed were the greatest problems of the farmers for rearing cattle. Hashem et al., (1999) reported that lack of training, lack of credit facilities, price variation in different markets, disorganized marketing systems are the problem for cattle fattening in Bangladesh.

\section{Conclusion}

It can be concluded that present status of organic beef cattle production in Bangladesh is not so good because majority of the farmers used cultivated fodder from unauthorized sources where different inorganic substances and pesticides are used. Most of the respondents used feed additives, hormones, antibiotics and growth promoter for beef cattle production and do not practiced isolation of sick or injured animal from healthy stock. In Bangladesh beef cattle production play a significant role to satisfy the animal protein requirement. It is also an emerging sector for improving socio economic condition of rural masses by generating employment and augmenting family income particularly small and marginal farmers in rural areas.

Bangladesh Journal of Extension Education 2 (1): 41-49.

Begum MAA, Hossain MM, Khan M, Rahman MM and RahmanSME (2007).Cattle fattening practices of selected farmers in Panchagarh district.Bangladesh Journal of Animal Science 36 (1-2): 62-72. 


\section{Beef cattle production in Bangladesh}

BER(Bangladesh Economic Review) (2012). Ministry of Planning, Government of the Peoples Republic of Bangladesh.

Chander M, Subrahmanyeswari B, Mukherjee R and Kumar $S$ (2011).Organic livestock production: an emerging opportunity with new challenges for producers in tropical countries. Rev. sci. tech. Off. int. Epiz. 30 (3): 969-983.

DLS (Directorate of Livestock Services) (2011). General information related to livestock. Monthly Fisheries and Livestock Bulletin, published by Fisheries and Livestock Information Office, Khamarbari, Farmgate, Dhaka, Bangladesh.

FAO (2010).Selected indicators of Food and Agriculture Development in Asia pacific region, 1993-2003. Food and Agriculture Organization of the United Nations, Bangkok, Thailand, pp, 119-121.

Hashem MA, Moniruzzaman M, Akhter $S$ and Hossain MM (1999).Cattle fattening by rural farmers in different district of Bangladesh.Bangladesh Journal of Animal Science 28 (1-2): 81-88.

Hossain KM, Nahar TN, Talukder AI and Kibria SS (1996a).Beef fattening by rural woman. In the proceedings of a National Workshop on case studies "Success stories of woman in Agriculture" 27-28 August 1995, BARC, Dhaka, Bangladesh.
Hossain MM (1986). Study of cattle fattening program by landless and youth.Bangladesh Journal of Animal Science 15 (1-2): 85-88.

Hossain MS, Hossain MM, Hashem MA and Ali RN (1996b). Transfer of feeding technology to promote cattle production of village level. Bangladesh Journal of Animal Science 25 (12): 51-56.

IFOAM 2000: IFOAM Basic Standards. International Federation of Organic Movements, TholeyTheley, (Also published at:www.ifoam.org/ standard / basics.htm).

Islam MH, Hashem MA, Hossain MM, Islam MS, Rana MS and Habibullah M (2012). Present status on the use of anabolic steroids and feed additives in small scale fattening in Bangladesh. Progressive Agriculture 23 (1-2): 1-13.

Kijlstra A and Eijck IAJM (2006).Animal health in organic livestock systems.Netherland Journal of Animal Science 54 (1): 77-94.

Rahman Z, Hossain MM and Hashem MA (2012).Cattle fattening program in dinajpur district of Bangladesh.Progressive Agriculture 23 (1-2): 1-13. 